\title{
Antimicrobial activity from ticks eggs waxes
}

\author{
Natalia Alduini", Marcos Silva, Marcia Franzolin, Ronaldo Mendonça, Solange Lima-Netto \\ From 5th Congress of the Brazilian Biotechnology Society (SBBIOTEC) \\ Florianópolis, Brazil. 10-14 November 2013
}

\section{Introduction}

Ticks lay their eggs in the environment and cover the eggs in a waxy layer to protect them from desiccation and microbial attack. This wax is produced by an organ known as Gene's Organ. Bio prospection has shown the presence of active principles in the hemolymph of arthropods as well as in the salivary glands of ticks. Some of these are of interest for the development of new pharmacological drugs. In this study, different tick species were used to test the antimicrobial effect of the extract obtained from the wax envolving the eggs.

\section{Objectives}

The objective of this study is to evaluate the antimicrobial effect of the waxy secretion from the eggs of the following tick species: Amblyomma cajennense, Amblyomma aureolatum, Rhipicephalus (Boophilus) microplus and Rhipicephalus sanguineus.

\section{Methods}

The egg masses were treated with icy cold phosphate buffer ( $\mathrm{pH}$ 6.8) to test against Influenza virus $\left(\mathrm{H}_{1} \mathrm{~N}_{1}\right)$ to determine the antiviral activity of the ticks eggs wax. MDCK cells were infected with influenza viruses, culture of MDCK cells, performed in 96 wells microplate, were treated with $2600,1300,650,325,162.5,82,41$ and $20.5 \mathrm{mg} / \mathrm{mL}$ of the eggs wax extract $1 \mathrm{~h}$ before infection. After $72 \mathrm{~h}$ post infection cytopathic effect induced by the virus was observed, the culture medium was removed and the cells in the plate were stained with crystal violet $(0.2 \%$ in $20 \%$ methanol). The egg wax was maintained in culture during the time of infection. The eggs were also treated with chloroform to obtain an extract suitable for the disc diffusion standard methodology stablished by Kirby and Bauer. The microorganisms used to test the activity were: Candida albicans, Micrococcus luteus, Escherichia coli, and Staphilococcus aureus. After incubation the plates were observed for the presence or absence of growth inhibition.

\section{Results}

Amounts as small as $325 \mathrm{mg} / \mathrm{mL}$ of the extract were able to inhibit the replication of the virus. Besides, the sample presented very low citotoxicity on Vero cells. On the other hand, the organic extract from A. aureolatum and $R$. sanguineus showed an inhibition zone for the strains of C. albicans, M.luteus, E.coli and S.aureus. This result is in accordance with the antimicrobial activity reported for the wax extracted from other ticks.

\section{Published: 1 October 2014}

\section{References}

1. Lima-Netto S, Pinheiro A, Nakano E, Zucatelli Mendonça RM, BarrosBattesti DM, Mendonça RZ: Antiviral effect of the egg wax of Amblyomma cajennense (Acari: Ixodidae). Cytotechnology 2012, 64(5):606-606.

2. Lima-Netto S, Mendonça R, Franzolin MR Utescher CL, Orozco S, MáximoEspindola CP, Labruna M, Barros-Battesti D: An interesting antimicrobial activity of egg wax from Amblyomma cajennense (Acari: Ixodidae). Systematic \& Applied Acarology 2011, 16(1):3-6.

3. Arrieta MC, Leskiw BK, Kaufman WR: Antimicrobial activity in the egg wax of the African cattle tick Amblyomma hebraeum (Acari: Ixodidae). Experimental and Applied Acarology 2006, 39(3-4):297-313.

4. Esteves E, Fogaça AC, Maldonado R, Silva FD, Manso PP, Pelajo-Machado M, Valle D, Daffre S: Antimicrobial activity in the tick Rhipicephalus (Boophilus) micropluseggs: Cellular localization and temporal expression of microplusin during oogenesis and embryogenesis. Developmental and Comparative Immunology 2009, 33(8):913-919.

\section{doi:10.1186/1753-6561-8-S4-P156}

Cite this article as: Alduini et al:: Antimicrobial activity from ticks eggs waxes. BMC Proceedings 2014 8(Suppl 4):P156. 